\title{
Severe tempering of bainite generated at low transformation temperatures
}

\author{
H. S. Hasan ${ }^{\mathrm{a}, \mathrm{b}}$, M. J. Peet ${ }^{\mathrm{b}}$, H. K. D. H. Bhadeshia ${ }^{\mathrm{b}}$ \\ ${ }^{a}$ University of Technology, Mechanical Engineering, Baghdad, Iraq \\ ${ }^{\mathrm{b}}$ University of Cambridge, Materials Science and Metallurgy, U.K.
}

The response of a strong bainitic-steel to tempering at high temperatures is investigated, because a softened state is sometimes necessary during the manufacture of engineering components, prior to the final heat-treatment which hardens the material. Thermodynamic calculations conducted to determine the maximum temperature at which the steel could be annealed without forming austenite were found to significantly overestimate the actual temperature at which austenite, ferrite and cementite $(\gamma+\alpha+\theta)$ can coexist in equilibrium. As a consequence, the tempering temperature must be limited to below about $700^{\circ} \mathrm{C}$, which unfortunately necessitates many days of tempering in order to reduce the hardness to $<250 \mathrm{HV}$. An alloy modification which may shorten this tempering time is suggested. One unexpected outcome is that the unintended heat treatment in the threephase field revealed useful information about the nucleation of pearlite on cementite particles. Colonies of pearlite started inevitably on particles of cementite located at the $\gamma / \alpha$ interfaces, rather than at similar particles enclosed completely by the austenite.

\section{Introduction}

Nanostructured steels based on bainite forming at temperatures as low as $200^{\circ} \mathrm{C}$ or less are now a commercial reality [1-4]. They have a structure which is a mixture of platelets of bainitic ferrite just 20-40 nm in thickness, and carbon-enriched retained austenite. The steel can be manufactured in huge quantities and with physical dimensions which are large in all directions, without the need for deformation or rapid processing. The bainitic ferrite itself contains carbon in excess of that expected from equilibrium [5-7]. This makes the steel strong with an ultimate tensile strength of about $2300 \mathrm{MPa}[8,9]$. In combination with the austenite that is retained, this gives a useful range of properties which have been exploited in the manufacture of armour [10]. There are other applications which are under active development: bearing manufacture [11], wear resistant surfacetreatments [12-15], shafts [16], automotive steel [17], sintered components [18], and the substitution of quenched and tempered steels [19].

One important aspect of the structure which is well-documented at a variety of resolutions [20], is that it is very hard, about $700 \mathrm{HV}$ [21] in its transformed state. The hardness originates from the very high density of interfaces present due to the fine scale of the bainitic ferrite plates and to a 
smaller extent from carbon at dislocations [20]. However, it is necessary in some applications such as bearings, to fabricate or machine the steel in a softened state [22]. Bainitic steels have been known for a long time to be much more resistant to tempering than those which are martensitic $[23,24]$. This is because unlike martensite, the strength of bainitic steels depends less on solidsolution strengthening by carbon; the thickness of the bainite plates dominates the overall strength. This is true also for the nanostructured bainite; quite severe tempering does not lead to dramatic reductions in the hardness because the retained austenite then decomposes into cementite and ferrite, with intense carbide precipitation precisely at the bainite plate boundaries, thereby pinning them [25]. Since much of the strength of this microstructure originates from the fine scale of the bainite plates, the steel is able to resist the loss of hardness until tempering leads to a loss of the plate shape.

The purpose of the present work was to study the severity of the heat-treatment necessary to eliminate the plate-like structure of the low-temperature bainite, so that a hardness level less than $250 \mathrm{HV}$ can be achieved.

\section{Experimental details}

The steel used belongs to the class of low-temperature bainite $[1,20,26,27]$ but with cobalt and aluminium added in order to reduce the transformation time from days to hours [28-30]. The chemical composition of the steel is given in Table 1 .

Table 1: Chemical composition, wt.\% of the steel studied.

\begin{tabular}{ccccccc}
\hline $\mathrm{C}$ & $\mathrm{Si}$ & $\mathrm{Mn}$ & $\mathrm{Mo}$ & $\mathrm{Cr}$ & $\mathrm{Co}$ & $\mathrm{Al}$ \\
\hline 0.78 & 1.6 & 2.02 & 0.25 & 1.01 & 3.87 & 1.37 \\
\hline
\end{tabular}

Samples $10 \times 13 \times 1.6 \mathrm{~mm}$ size were sealed in quartz tubes, austenitised at $950^{\circ} \mathrm{C}$ for $30 \mathrm{~min}$ and isothermally transformed at $200^{\circ} \mathrm{C}$ for 3 days in order to produce nanostructured bainite, as illustrated in Fig. 1; further details can be found in [31]. Samples with this microstructure were then tempered at 508, 608, 708 and $753^{\circ} \mathrm{C}$ for time periods between a half an hour and 42 days. Furnace temperatures were measured using a calibrated $\mathrm{K}$-type thermocouple positioned in a quartz tube in the same location as the sample. Additional investigations were conducted on the samples heat treated at $753{ }^{\circ} \mathrm{C}$ because, as described later, the results were not consistent with expectations from phase diagram calculations.

Cylindrical samples of $8 \mathrm{~mm}$ diameter and $12 \mathrm{~mm}$ length were also transformed to the bainitic microstructure using the heat treatment described above. These samples were heated in a Thermecmaster dilatometer described elsewhere [32] in order to determine the austenite formation temperature during heating.

X-ray experiments were conducted on a Philips PW1830 diffractometer using $\mathrm{Cu}-\mathrm{K}_{\alpha}$ radiation, $45 \mathrm{kV}$ and $45 \mathrm{~mA}$, with scanning at $0.1^{\circ} \mathrm{min}^{-1}$ over $20^{\circ} \leq 2 \theta \leq 110^{\circ}$. Carbides were extracted 
for X-ray characterisation by dissolving the ferrite using nital, with the residue filtered through a $0.1 \mu \mathrm{m}$ pore size cellulose nitrate membrane; in this case the scan step size was $0.02^{\circ}$. The Vickers hardness values reported represent an average of five measurements conducted using a $50 \mathrm{~kg}$ load.

\section{Phase diagram and heating experiments}

The original choice of tempering temperatures was based on phase diagram calculations using MTDATA [33] and the SGTE_plus database [34], allowing cementite, $M_{23} \mathrm{C}_{6}, M_{6} \mathrm{C}, M_{7} \mathrm{C}_{3}, M \mathrm{C}$, ferrite and austenite to exist as possible phases (the ' $M$ ' stands for metal atoms). Use of the TCFE database made no significant difference to the outcome. As can be seen from Fig. 2a, the formation of austenite under equilibrium conditions should begin at about $795^{\circ} \mathrm{C}$ and be completed at $915^{\circ} \mathrm{C}$, so the highest tempering temperature was selected to be about $750^{\circ} \mathrm{C}$. However, when experiments were conducted, the austenite formation temperature was found to be much lower than that predicted by the phase diagram calculation. These experiments will be reported later, but dilatometry confirmed that the calculations in fact overestimate the $A e_{1}$ temperature beyond which austenite formation becomes thermodynamically possible, with the $A c_{1}$ temperature in practice being lower by at least $50^{\circ} \mathrm{C}$, Fig. $2 \mathrm{~b}$.

\section{Hardness}

Every single value of recorded hardness is plotted in Fig. 3 in order to illustrate the scatter in individual samples. It is expected from elementary kinetic theory that the hardness during tempering should vary approximately linearly with the logarithm of time [35], as confirmed by experimental investigations on the tempering of martensitic steels in the absence of secondary hardening [36-38].

It is common in tempering studies to use a tempering parameter to rationalise the effects of time and temperature $[35,39,40]$; this also includes a logarithmic dependence on time. The parameter is defined as $T(20+\log t)$ where $T$ is expressed in Kelvin and $t$ in hours. The normalised hardness is given by $\left(H-H_{\min }\right) /\left(H_{\max }-H_{\min }\right)$, where $H, H_{\max }$ and $H_{\min }$ represent the hardness, untempered hardness and fully-softened hardness respectively. Although commonly applied to martensitic steels, it has been used for precisely the type of bainite considered here, albeit for a steel of a different chemical composition [25]. Figure 3b compares the data from the present work with the curve from the previous work [25] which was designed to look at the stability of the retained austenite. All the new data fall close to the original curve with the exception of the values from the $753{ }^{\circ} \mathrm{C}$ tempering experiments, where only the short heat-treatment time data approach the general trend. This anomalous behaviour will be discussed later in the context of metallographic observations. 


\section{Metallography}

The intention of the heat treatment at $753{ }^{\circ} \mathrm{C}$ was simply to temper at the highest temperature before austenite formation sets in. However, the calculations overestimated the $A e_{1}$ temperature and hence the heat treatment led to the formation of some austenite, i.e, the samples were intercritically annealed in the three phase $\alpha+\gamma+\theta$ phase field, where the symbols stand for ferrite, austenite and cementite, respectively, rather than undergoing the intended tempering heat treatment. The results were nevertheless revealing in several respects.

Figure 4 shows the evolution of the microstructure during heat treatment at $753^{\circ} \mathrm{C}$; note that the samples were quenched following the elevated temperature heat treatment. During the first $30 \mathrm{~min}$ at temperature, cementite precipitates from the high-carbon retained austenite in the original structure, forming arrays along the bainite plate edges; at the same time, the austenite (which transforms into martensite on quenching) grows to fill almost half of the specimen, although the distinct plate shapes of the bainite sheaves are coarsened but essentially retained (Fig. 4a). Continued heat treatment (Fig. 4b) reveals more clearly that the regions where austenite has grown are relatively free from cementite, whereas those carbides isolated from the austenite are coarse; this is because the solubility of carbon in austenite which is in equilibrium with cementite is greater than the corresponding equilibrium with ferrite. The plate like features of the original structure are still retained. Major changes are seen for the 20 days of tempering (Fig. 4c), with clear coarsening of the ferrite, and a huge difference in the size of cementite particles which are surrounded by austenite and much coarser ones lying with the ferrite. Following 42 days of heat treatment (Fig. 4d), the austenite has presumably approached its equilibrium fraction and hence a lower carbon concentration; as a result, the quench was not completely effective in suppressing the formation of small quantities of pearlite. X-ray diffraction revealed a small amount of retained austenite within the predominantly martensitic regions, and the carbides were identified as cementite using extracted residues, Fig. 5.

We note that the presence of martensite, due to the formation of austenite, explains why the hardness of the samples heat treated at $753{ }^{\circ} \mathrm{C}$ (Fig. 3b) does not follow the general trend.

Although tempering at $753^{\circ} \mathrm{C}$ did not lead to the intended effects, the resulting metallography is quite dramatic and reveals information about the early stages of pearlite formation. Figures $6 \mathrm{a}$ and b show pearlite beginning from coarse particles of cementite which have physical contact with both ferrite and austenite; these observations are typical. In contrast, none of the cementite particles enclosed within the austenite were found to be associated with fledgling colonies of pearlite, as illustrated in Fig. 6c. As shown in the inset on Fig. 6a, there is no significant difference in the chromium concentration (or other substitutional solutes not plotted) between these two kinds of cementite particles. The conclusion therefore must be that pearlite nucleation occurs more readily at cementite particles which are in simultaneous contact with both ferrite and austenite. This is reasonable because the formation of a pearlite colony proper involves the cooperative growth of ferrite and cementite. Furthermore, this is a diffusional transformation and does not necessarily rely on the existence of specific orientation relationships between the parent and product phases; thus, it is well known that pearlite can grow across austenite grain boundaries in fully austenitic samples. 
While metallography has been conducted on tempering at all the temperatures studied, we present further results only from the treatment at $708^{\circ} \mathrm{C}$ in order to demonstrate that the temperature is below $A e_{1}$ so that austenite formation is completely avoided. Figure 7 shows that the microstructure is very resistant to tempering, but the absence of austenite, and hence of martensite, leads to a much lower hardness as shown in Fig. 3a than following heat treatment at $753^{\circ} \mathrm{C}$.

It is generally considered that a hardness of $230 \mathrm{HV}$ or less is appropriate for the fabrication and easy-machining of steel for complex components such as bearings [22, 41]. The $708^{\circ} \mathrm{C}$ heat treatment, for 42 days, does not achieve this, and the time period required is simply too long in any case. Speroidisation from a martensitic condition which begins with fine carbides also takes too long to achieve such a low hardness in a high-carbon steel. As a consequence, a method was developed some time ago [42-44], involving the transformation of austenite into divorced pearlite, illustrated schematically in Fig. 8. Proeuctectoid particles present in the austenite simply absorb the excess carbon that is partitioned into the austenite as ferrite forms on cooling, thus leading to coarse cementite particles in a matrix of ferrite, i.e., a spheroidised structure by continuous cooling. This process is used routinely with the high-carbon steels for bearings [22]. Unfortunately, this particular procedure is not feasible for the present alloy because as shown in Fig. 2a, the alloy becomes essentially fully austenitic once the ferrite disappears, whereas a divorced eutectoid requires the existence of particles of cementite within an otherwise austenitic phase.

A heat treatment was attempted with the aim of making the material fully austenitic, then cooling to allow proeutectoid cementite, and then hoping for a divorced eutectoid transformation. The precise form is as used in the bearing steel industry $[22,45]$, but beginning with the low-temperature bainite with a hardness of $660 \pm 4 \mathrm{HV}$ :

$$
\begin{array}{r}
800^{\circ} \mathrm{C}, 1 \mathrm{~h} \rightarrow \text { cool to } 750^{\circ} \mathrm{C} \text { at } 25 \mathrm{~K} \mathrm{~h}^{-1} \rightarrow \operatorname{cool} \text { to } 690 \mathrm{~K} \text { at } 10 \mathrm{~K} \mathrm{~h}^{-1}, \\
\rightarrow \text { cool to room temperature at } 360 \mathrm{~K} \mathrm{~h}^{-1} .
\end{array}
$$

This led to a mixed microstructure of lamellar and divorced pearlite structure with a hardness of $301 \pm 4 \mathrm{HV}$, presumably because as suggested by theory [45], an appropriate dispersion of cementite particles is required in order to induce a fully divorced pearlite, Fig. 9a. It is also interesting to note that cooling to $750^{\circ} \mathrm{C}$ did not cause ferrite formation because the kinetics of this reaction are extremely slow in alloys of this class, due to their high hardenability [46].

The presence of ferrite may help soften the material, and as shown previously, coarse ferrite can be introduced into the microstructure by heat treatment at $753^{\circ} \mathrm{C}$, with the aim of transforming any austenite that forms into pearlite rather than martensite. This was achieved by holding the initial mixture of bainitic ferrite and retained austenite, at $753^{\circ} \mathrm{C}$ for $13 \mathrm{~h}$, then cooling rapidly to $650^{\circ} \mathrm{C}$ to transform any austenite into pearlite. The hardness of this structure (Fig. $9 \mathrm{~b}$ ) was found to be $552 \pm 3 \mathrm{HV}$.

On the other hand, it is clearly possible to obtain a structure in which $\alpha, \gamma$ and $\theta$ co-exist, with cementite particles present in both of the major phases. 


\section{Conclusions}

1. It has been difficult to achieve sufficient softening in a structure which is initially a fine mixture of platelets of bainitic ferrite separated by films of carbon-enriched retained austenite except by using impractically long heat-treatments. The decomposition of films of austenite leads to arrays of carbides at the ferrite plate boundaries, preventing them from coarsening.

2. Tempering treatments are limited to below about $750{ }^{\circ} \mathrm{C}$ in order to avoid the formation of austenite.

3. Continuous cooling spheroidisation treatments of the kind exploited in the bearings industry are also ineffective due to the absence of the proeutectoid cementite particles needed to form divorced pearlite.

4. The carbon concentration of the steel should be increased to permit a dispersion of cementite particles within the austenite at the austenitisation temperature. These particles should then simply grow to absorb any carbon that is partitioned by ferrite as the steel is cooled through the eutectoid temperature, thereby promoting a spheroidised microstructure.

The authors are grateful to British Universities Iraq Consortium and the Council for Assisting Refugee Academics (CARA) for funding this work, to the Ministry of Education \& Scientific Research in Iraq, and to the University of Cambridge for the provision of laboratory facilities. 


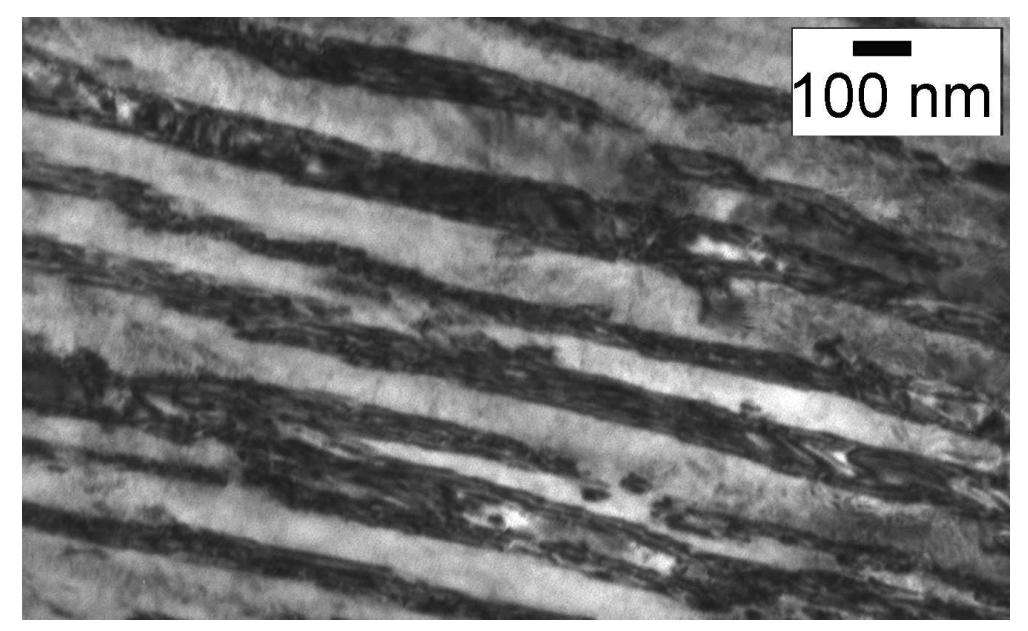

Figure 1: The initial nanostructure obtained following transformation at $200^{\circ} \mathrm{C}$ for 3 days, consisting of platelets of ferrite (light) separated by films of austenite. The mean free slip distance in such a structure is twice the true thickness of the plates. Much more metallographic information including quantitative measurements has been reviewed in [31], which contains many original references.
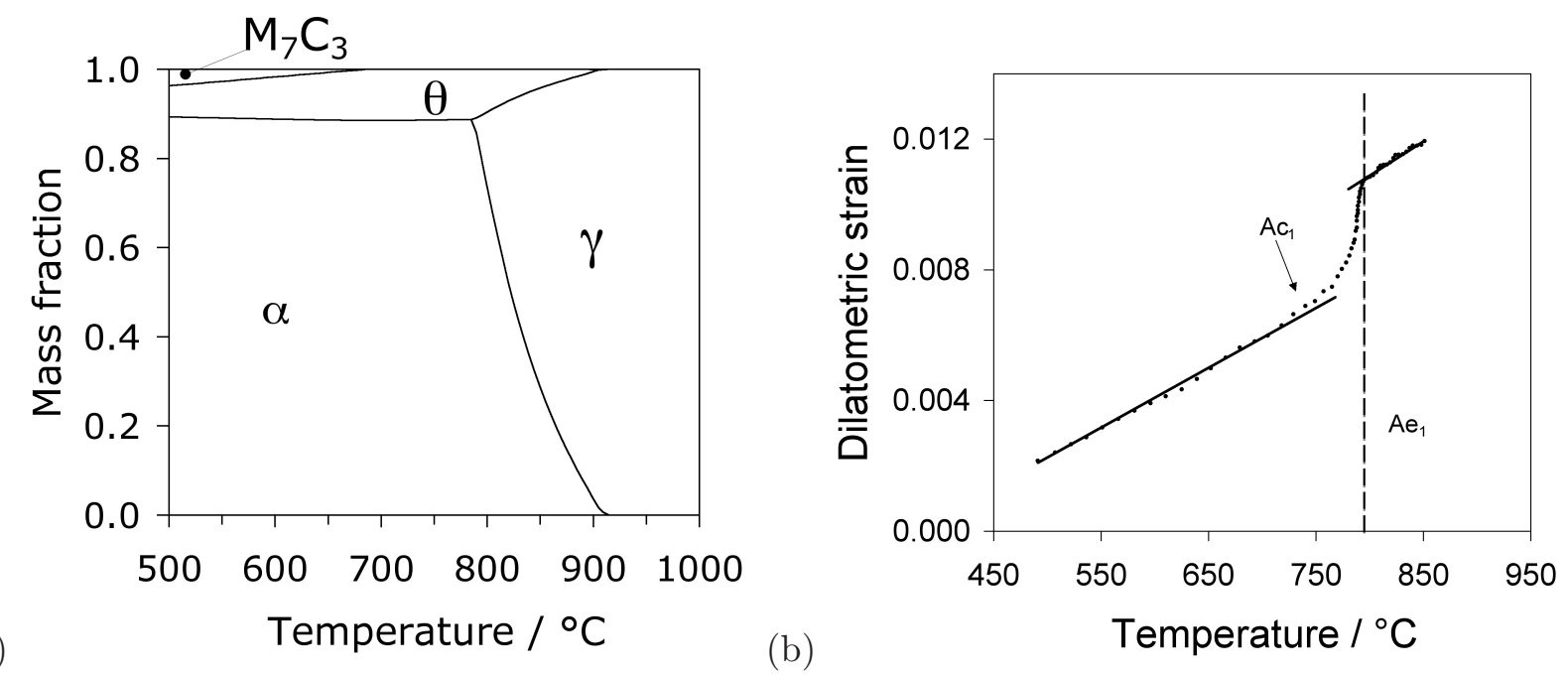

Figure 2: (a) Calculated equilibrium phase fractions of ferrite $(\alpha)$, austenite $(\gamma)$, cementite $(\theta)$ and $M_{23} \mathrm{C}_{6}$, as a function of temperature. (b) Dilatometric strain recorded during heating at $30 \mathrm{~K} \mathrm{~s}^{-1}$. 

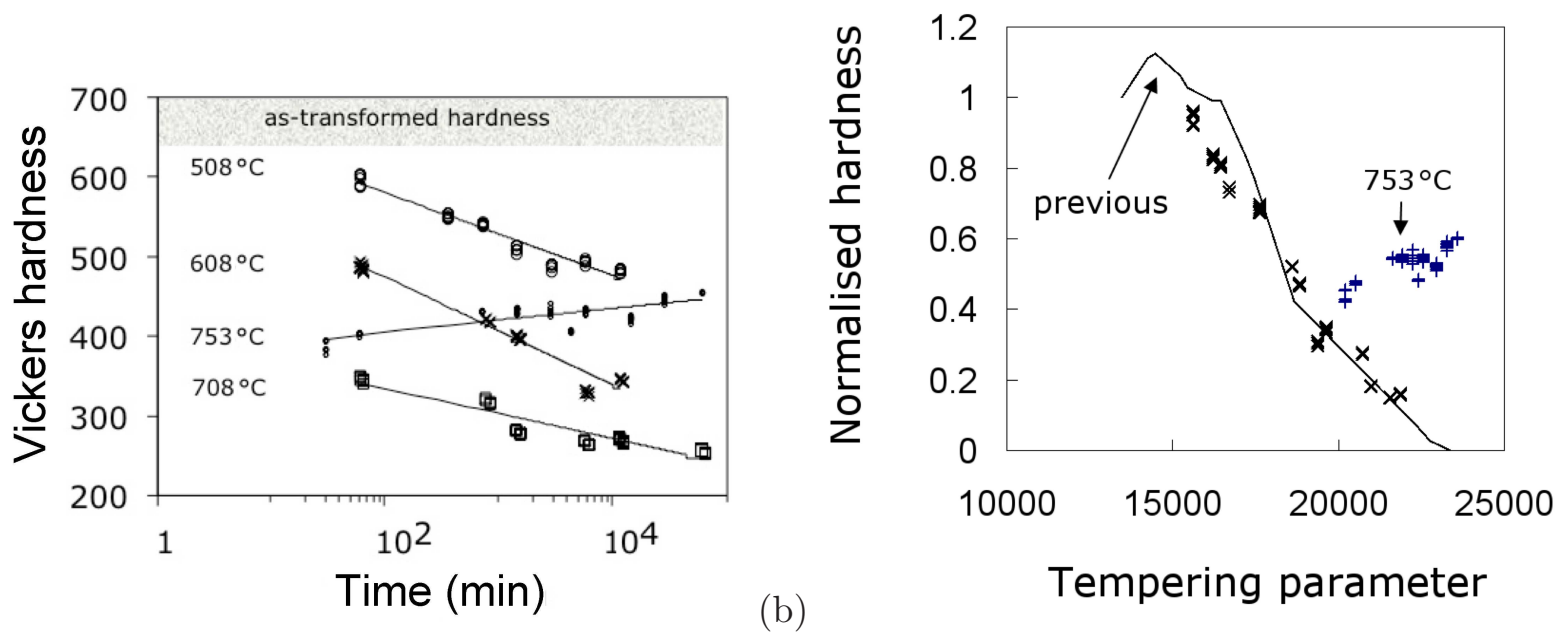

Figure 3: (a) Hardness as a function of the logarithm of time. (b) The normalised hardness versus the tempering parameter $T(20+\log t)$ where $T$ is expressed in Kelvin and $t$ in hours. The line represents published work on a different steel, Fe $-0.98 \mathrm{C}-1.46 \mathrm{Si}-1.89 \mathrm{Mn}-1.26 \mathrm{Cr}-0.26 \mathrm{Mo}-0.09 \mathrm{~V}$ wt.\%, with the same kind of nanostructured bainite [25] whereas the points are from the present measurements. 

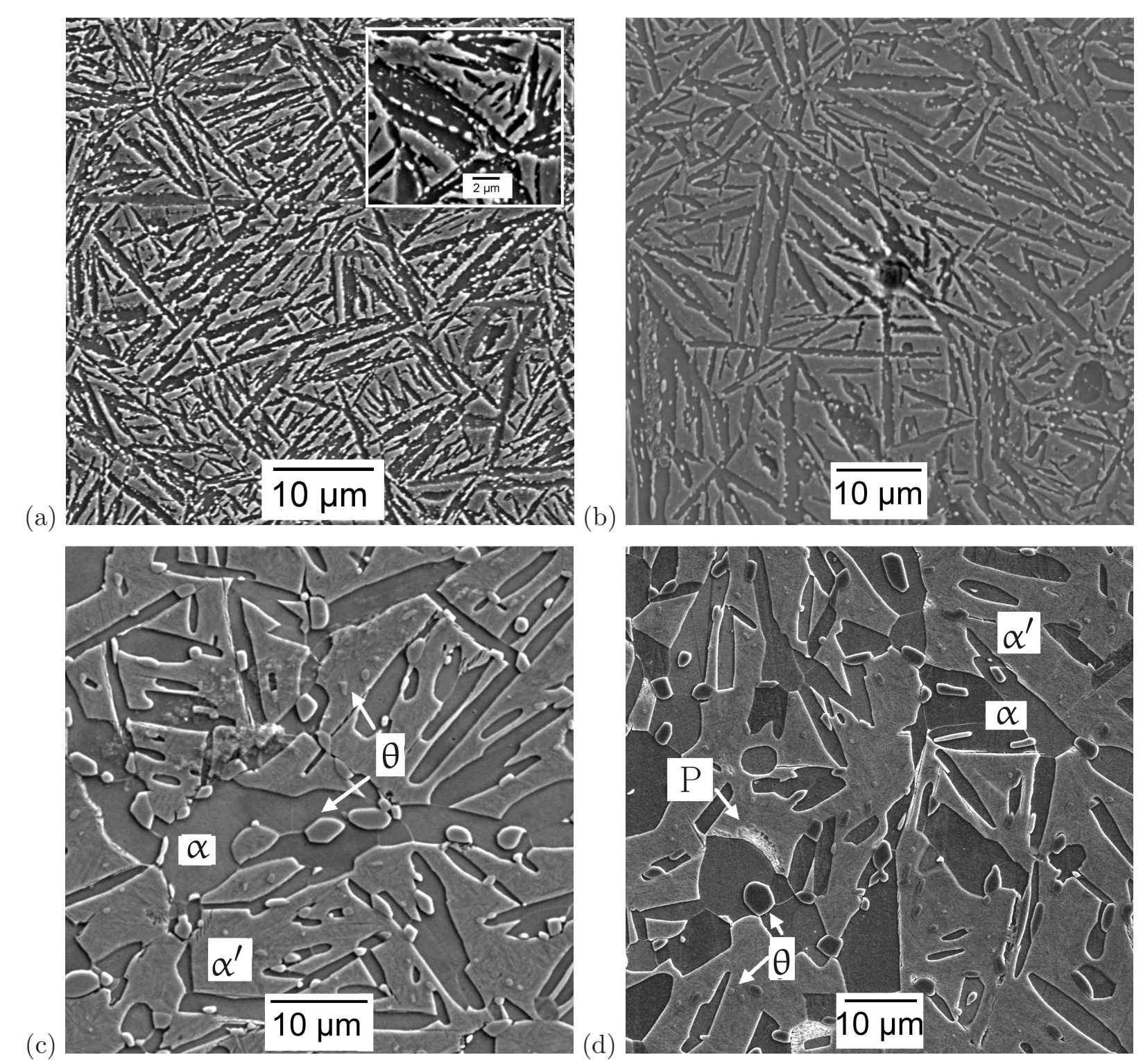

Figure 4: Samples tempered at $753{ }^{\circ} \mathrm{C}$ for a variety of time periods. The symbols $\alpha, \alpha^{\prime}, \theta$ and $\mathrm{P}$ stand for ferrite, martensite, cementite and pearlite respectively. (a) After $30 \mathrm{~min}$, showing the precipitation of carbides. (b) After $12 \mathrm{~h}$, with austenite (now $\alpha^{\prime}$ ) formation and dissolution of some carbides. (c) After 20 days of tempering. (d) After 42 days of tempering. 

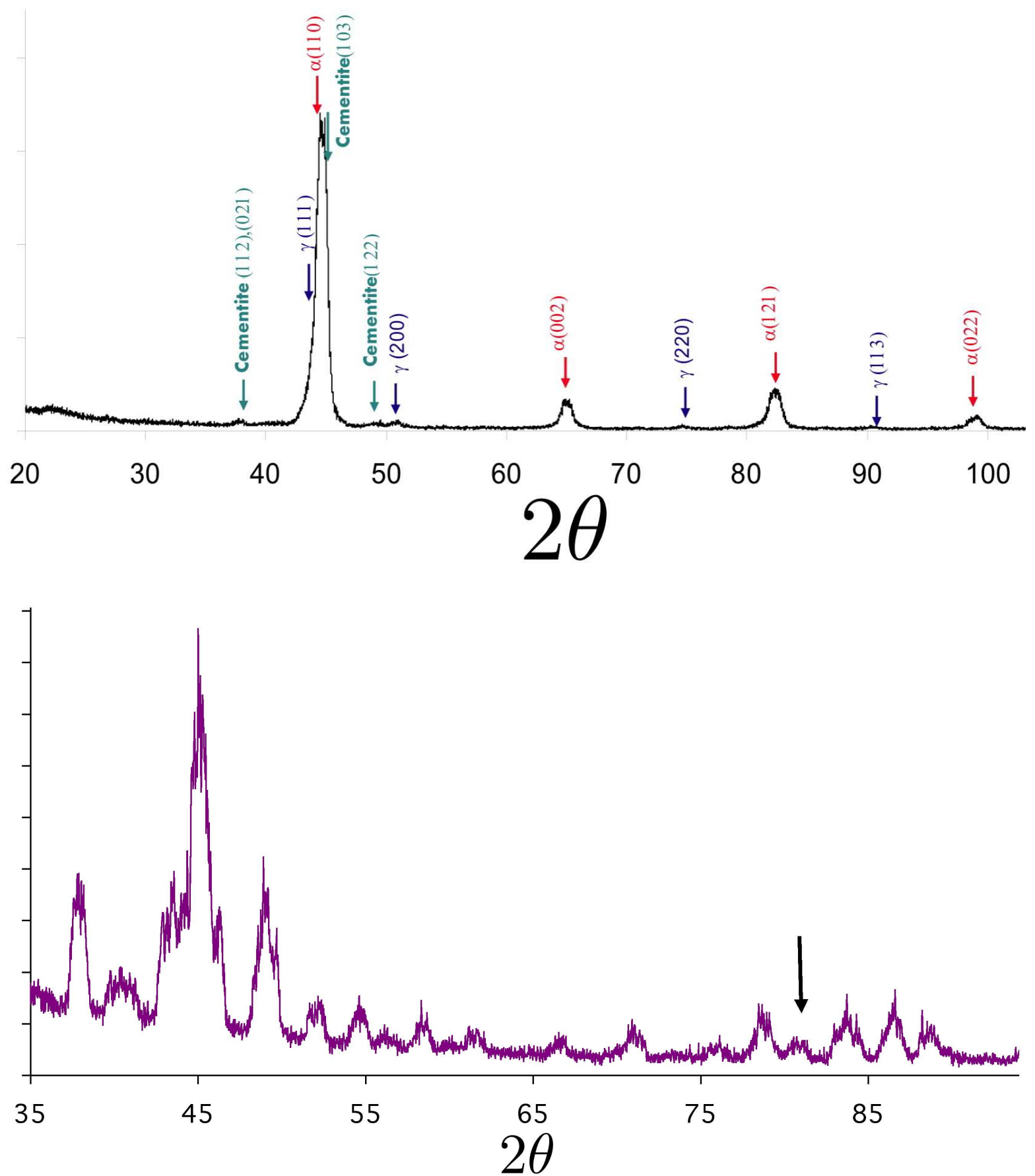

Figure 5: Sample heat-treated at $753^{\circ} \mathrm{C}$ for 42 days. (a) $\mathrm{X}$-ray diffraction pattern, showing the presence of a discernible amount of retained austenite. (b) X-ray diffraction from extracted residue. All the peaks can be attributed to cementite, with the exception of the unidentified peak at the position of the arrow. 

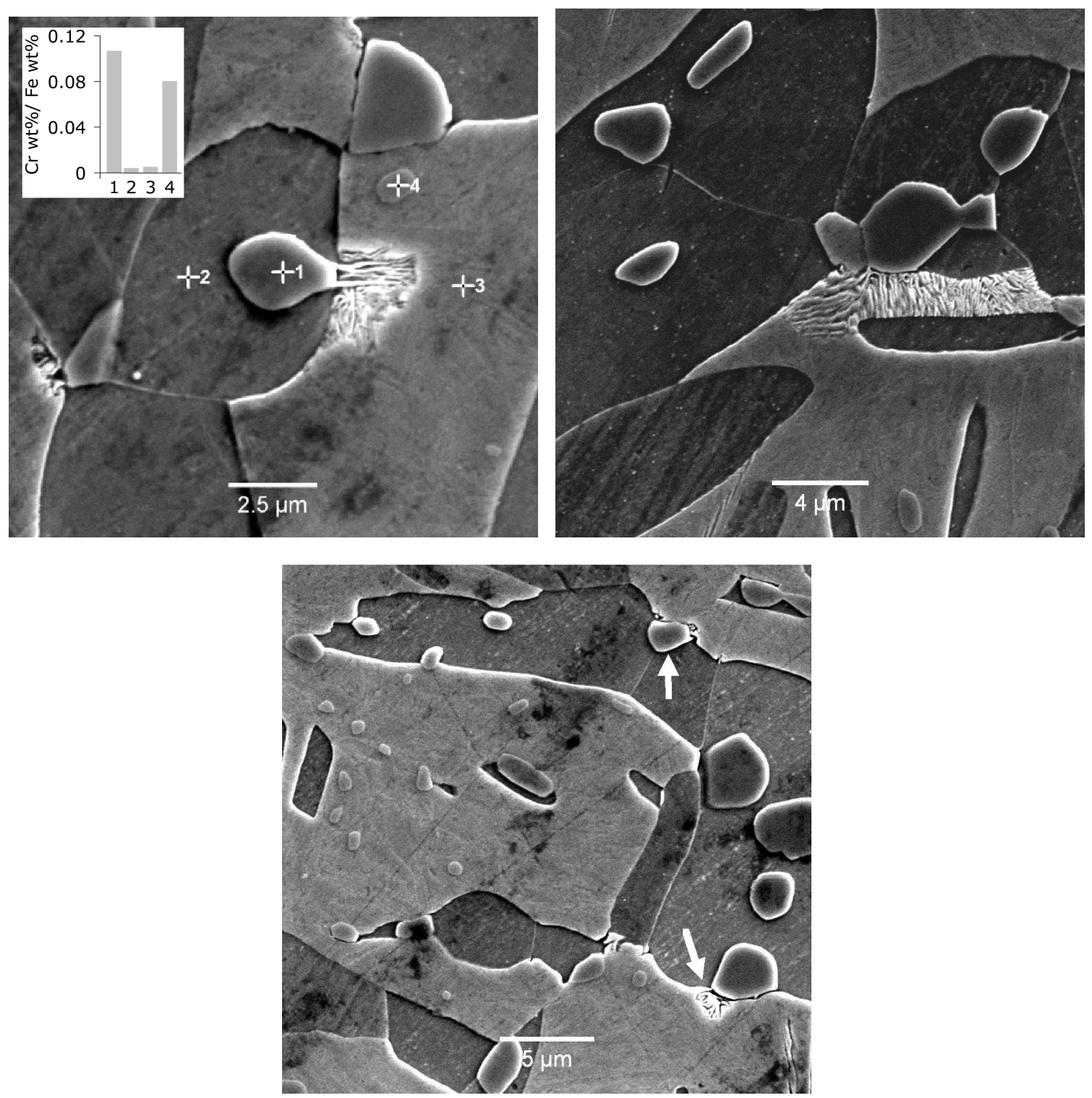

Figure 6: Sample heat-treated at $753^{\circ} \mathrm{C}$ for 42 days. The $\mathrm{Cr} / \mathrm{Fe}$ ratios marked 1, 2, 3, 4 have errors of $\pm 0.03,0.2,0.2$ and 0.03 respectively. $(a, b)$ Showing the genesis of pearlite at particles of cementite which are in contact with both ferrite and austenite. (c) The arrows show minute colonies of pearlite at $\gamma-\alpha-\theta$ interfaces, but not at the numerous cementite particles trapped within the austenite. 
(a)
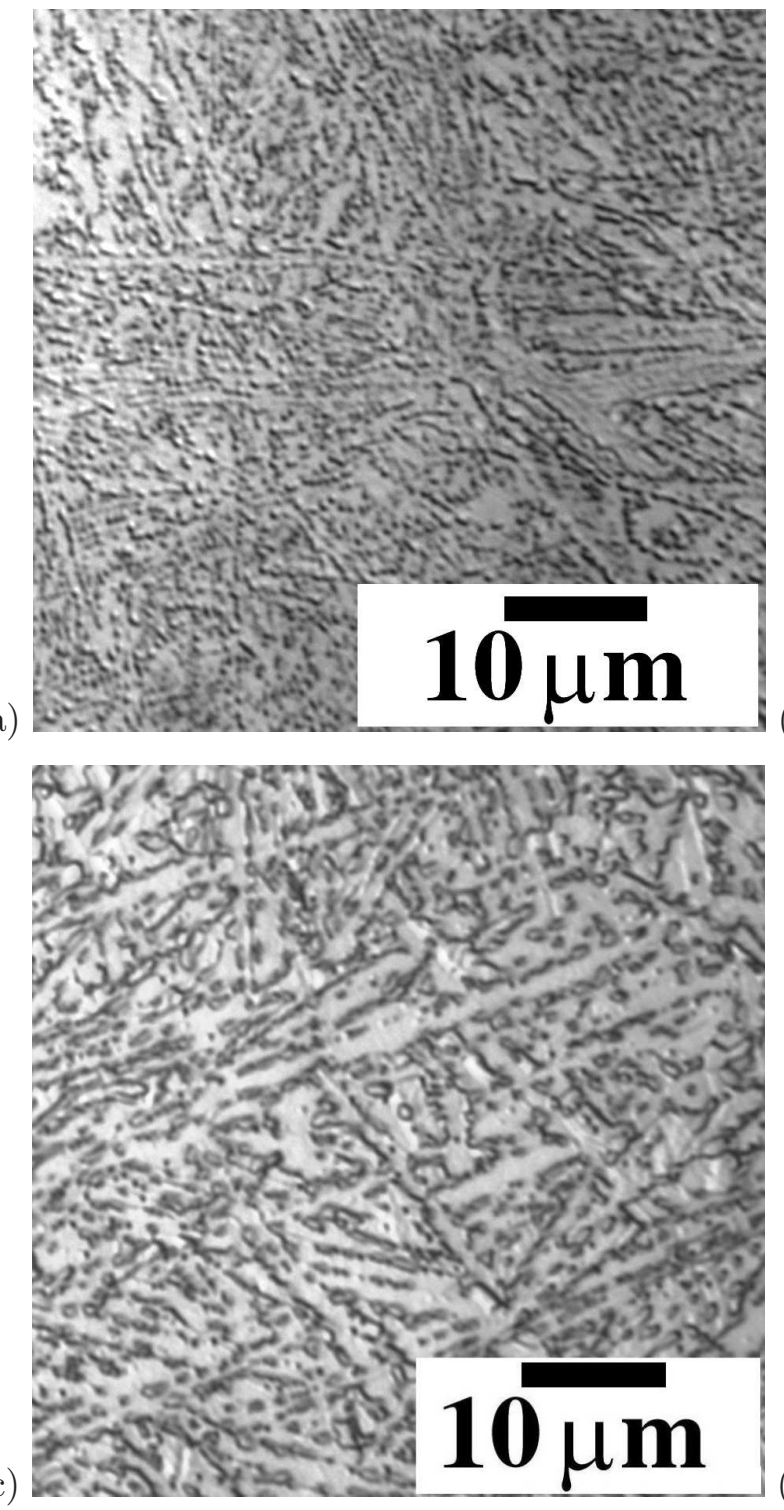
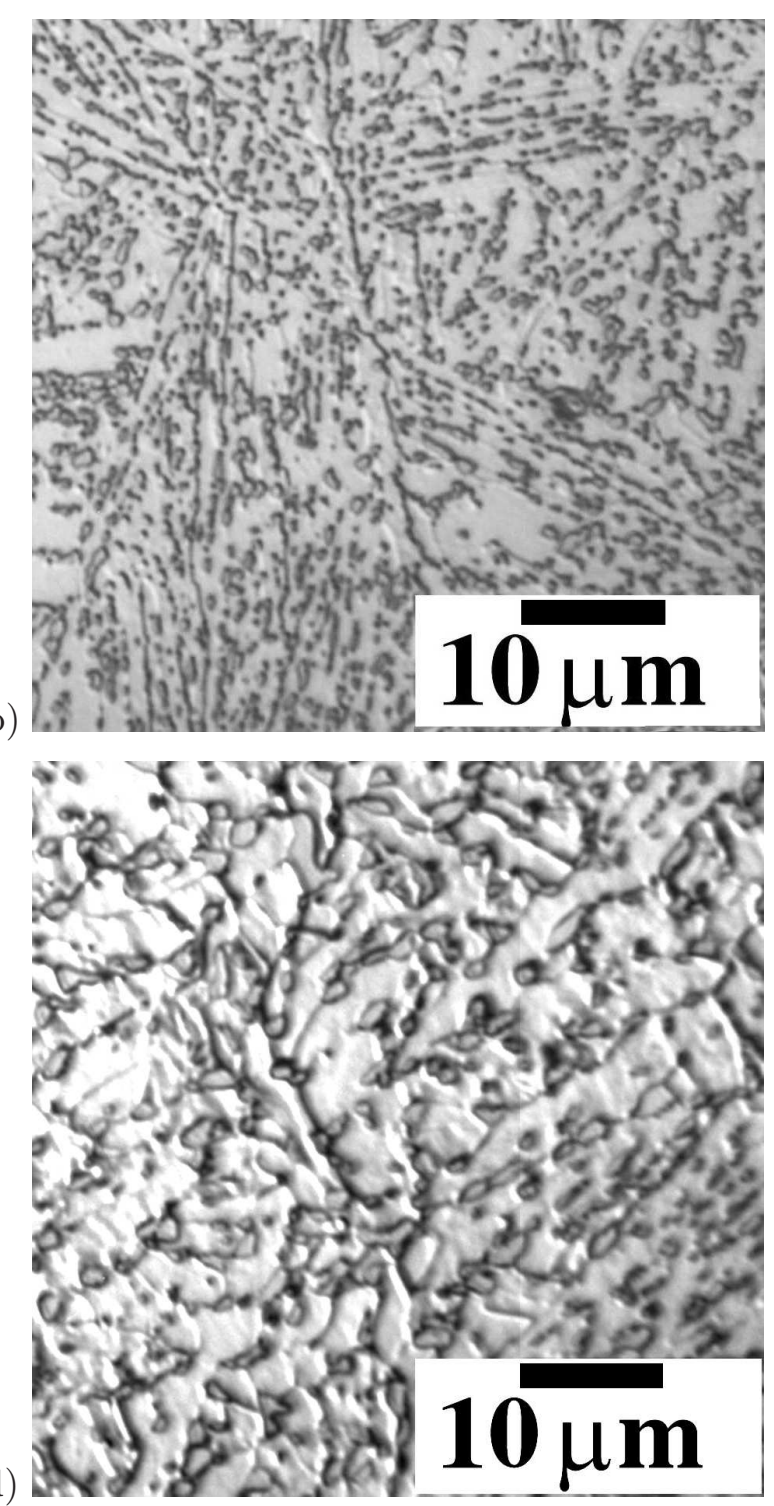

Figure 7: Samples tempered at $708^{\circ} \mathrm{C}$ for a variety of time periods. (a) After 1 day, (b) 4 days, (c) 8 days and (d) 42 days at the tempering temperature.

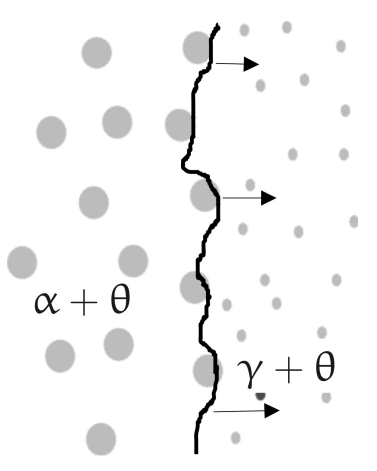

Figure 8: The mechanism of the divorced eutectoid transformation of a mixture of austenite and fine cementite 

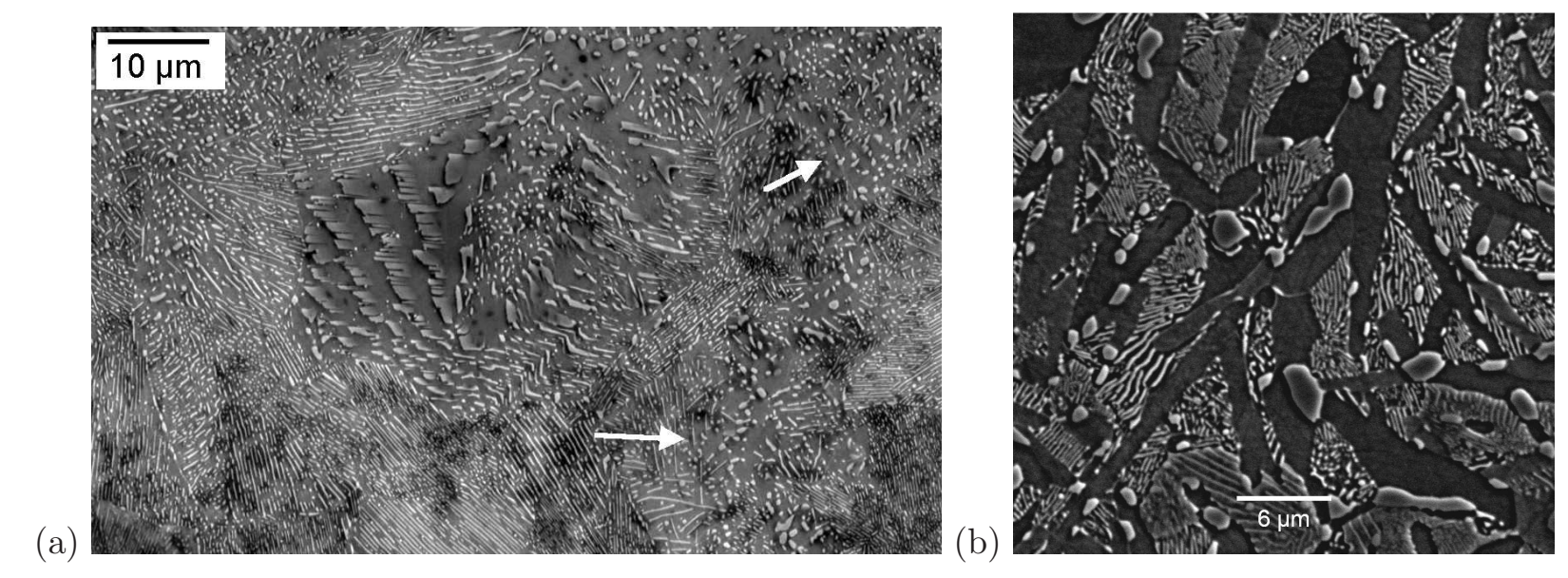

Figure 9: (a) Mixed microstructure of divorced (arrowed) and lamellar pearlite generated by a complex continuous cooling heat treatment of the type used for bearing steels. (b) Pearlite generated during isothermal transformation at $650^{\circ} \mathrm{C}$ in a partially austenitic sample obtained by heat treatment at $753^{\circ} \mathrm{C}$. 


\section{References}

[1] F. G. Caballero, H. K. D. H. Bhadeshia, K. J. A. Mawella, D. G. Jones, P. Brown: Mater. Sci. Tech. - Lond. 18 (2002) 279-284.

[2] C. G. Mateo, H. K. D. H. Bhadeshia: Mater. Sci. Eng. A - Struct. 378A (2004) 289-292.

[3] P. M. Brown, D. P. Baxter: Hyper-strength bainitic steels: in: Materials Science and Technology 2004: TMS, Warrendale, Pennsylvania, USA, 2004: pp. 433-438.

[4] S. J. Paynter: B.Sc. thesis, effects on the hardness of superbainite through isothermal heattreatment (2006).

[5] H. K. D. H. Bhadeshia, A. R. Waugh: Acta Metall. 30 (1982) 775-784.

[6] M. Peet, S. S. Babu, M. K. Miller, H. K. D. H. Bhadeshia: Scr. Mater. 50 (2004) 1277-1281.

[7] F. G. Caballero, M. K. Miller, S. S. Babu, C. Garcia-Mateo: Acta Mater. 55 (2007) 381-390.

[8] C. Garcia-Mateo, F. G. Caballero: Mater. Trans. 46 (2005) 1839-1846.

[9] H. K. D. H. Bhadeshia: Mater. Sci. Eng. A - Struct. 481-482 (2008) 36-39.

[10] H. K. D. H. Bhadeshia: Mater. Sci. Tech. - Lond. 21 (2005) 1293-1302.

[11] P. Zhang, F. C. Zhang, Z. G. Yan, T. S. Wang, L. H. Qian: Mater. Sci. Forum 675-677 (2011) $585-588$.

[12] T. S. Wang, J. Yang, C. J. Shang, X. Y. Li, B. Lv, M. Zhang, F. C. Zhang: Surf. Coat. Tech. 202 (2008) 4036-4040.

[13] F. C. Zhang, T. S. Wang, P. Zhang, C. L. Zhang, B. Lv, M. Zhang, Y. Z. Zhang: Scr. Mater. 59 (2008) 294-296.

[14] P. Zhang, F. C. Zhang, Z. G. Yan, T. S. Wang, L. H. Qian: Wear 271 (2011) 697-704.

[15] P. Zhang, F. C. Zhang, T. S. Wang: Appl. Surf. Sci. 257 (2011) 7609-7614.

[16] M. J. Peet, P. Hill, M. Rawson, S. Wood, H. K. D. H. Bhadeshia: Mater. Sci. Tech. - Lond. 27 (2011) 119-123.

[17] S. Khare, K. Y. Lee, H. K. D. H. Bhadeshia: Metall. Mater. Trans. A 41A (2010) 922-928.

[18] C. Menapace, I. Lonardelli, M. Tait, A. Moinari: Mater. Sci. Eng. A - Struct. 517 (2009) 1-7.

[19] J. A. da Cruz, T. F. M. Rodrigues, V. D. C. Viana, D. B. Santos: Mater. Sci. Forum 706-709 (2012) 173-180.

[20] F. G. Caballero, H. K. D. H. Bhadeshia: Curr. Opin. Sol. St. M. 8 (2004) 251-257.

[21] C. Garcia-Mateo, F. G. Caballero, H. K. D. H. Bhadeshia: ISIJ Int.l 43 (2003) 1238-1243.

[22] H. K. D. H. Bhadeshia: Prog. Mater. Sci. 57 (2012) 268-435. 
[23] K. J. Irvine, F. B. Pickering, W. C. Heselwood: J. Iron Steel I. 186 (1957) 54-67.

[24] K. J. Irvine, F. B. Pickering, W. C. Heselwood, M. Atkins: J. Iron Steel I. 186 (1957) 54-67.

[25] C. Garcia-Mateo, M. Peet, F. G. Caballero, H. K. D. H. Bhadeshia: Mater. Sci. Tech. - Lond. 20 (2004) 814-818.

[26] F. G. Caballero, H. K. D. H. Bhadeshia, K. J. A. Mawella, D. G. Jones, P. Brown: Mater. Sci. Tech. - Lond. 17 (2001) 512-516.

[27] F. G. Caballero, H. K. D. H. Bhadeshia, K. J. A. Mawella, D. G. Jones, P. Brown: Mater. Sci. Tech. - Lond. 17 (2001) 517-522.

[28] E. Houdremont, H. Schrader: Arch. Eisen. 10 (1932) 523A-534A.

[29] C. Garcia-Mateo, F. G. Caballero, H. K. D. H. Bhadeshia: ISIJ Inter. 43 (2003) 1821-1825.

[30] H. I. Aaronson, H. A. Domian, G. M. Pound: TMS-AIME 236 (1966) 781-796.

[31] H. K. D. H. Bhadeshia: Proc. Roy. Soc. A - Math. Phys. 466 (2010) 3-18.

[32] S. Kundu, K. Hase, H. K. D. H. Bhadeshia: Proc. Roy. Soc. A - Math. Phys. 463 (2007) 2309-2328.

[33] NPL: MTDATA: Software, National Physical Laboratory, Teddington, U.K. (2006).

[34] K. Hack (Ed.): The SGTE Casebook: Thermodynamics at work: The Institute of Materials, London, 1996.

[35] J. H. Hollomon, L. D. Jaffe: Trans. Met. Soc. AIME 162 (1945) 223-249.

[36] E. D. Hyam, J. Nutting: J Iron Steel I. 184 (1956) 148-165.

[37] G. R. Speich: Trans. Met. Soc. AIME 245 (1969) 2553-2564.

[38] G. R. Speich, W. C. Leslie: Metall. Trans. 3 (1972) 1043-1054.

[39] F. R. Larson, J. Miller: Trans. ASME 74 (1952) 765-781.

[40] R. A. Grange, C. R. Hribal, L. F. Porter: Metall. Trans. A 8A (1977) 1775-1785.

[41] W. Li, Y. Wang, X. Z. Yang: Trib. Lett. 18 (2005) 353-357.

[42] J. H. Whitley: J. Iron and Steel I. 105 (1922) 339-357.

[43] S. L. Gertsman: Research and special projects report for 1965: Tech. rep.: Canadian Department of Mines and Technical Surveys: Otawa, Canada (1966).

[44] J. D. Verhoeven, E. D. Gibson: Metall. Mater. Trans. A 29 (1998) 1181-1189.

[45] J. D. Verhoeven: Metall. Mater. Trans. A 31 (2000) 2431-2438.

[46] C. Garcia-Mateo, F. G. Caballero, H. K. D. H. Bhadeshia: J. Phys. Colloque 112 (2003) $285-288$. 